\title{
Marcadores moleculares asociados a resistencia antimalárica en la región Caribe Colombiana: Estado del conocimiento
}

\section{Molecular markers associated with antimalarial drug resistance in the Colombian Caribbean: State of knowledge}

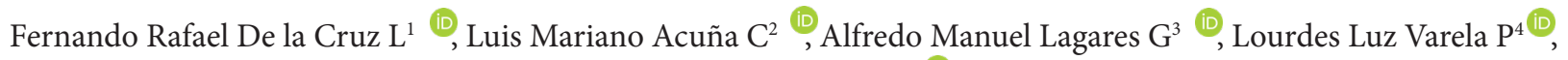
Dary Luz Mendoza $\mathrm{M}^{5}$.

\section{RESUMEN}

Objetivo: Revisar el estado del conocimiento de marcadores moleculares asociados a resistencia antimalárica en la región Caribe. Materiales y métodos: Se realizó una revisión sistemática de literatura científica sobre marcadores moleculares asociados a resistencia antimalárica en la región Caribe. La búsqueda se hizo en bases de datos utilizando estos criterios: "PCR" "Plasmodium falciparum" "Plasmodium vivax" "Resistencia" "Antimalárica" "genes" en los departamentos de: Atlántico, Bolívar, Cesar, La Guajira, Magdalena, Sucre y Archipiélago de San Andrés, Providencia y Santa Catalina entre 2000-2020. Resultados: Se incluyeron cuatro estudios en los departamentos de Sucre (2005), Magdalena (2010) y Bolívar (2013 y 2017), se identificaron las variantes genéticas S108N en pfdhfr y A437G en pfdhps de P. falciparum en Sucre y Bolívar respectivamente, K76T en pfcrt de P.falciparum en Magdalena y F1076L
- Y976F de pvmrd-1 en P.vivax de Bolívar. Los estudios del departamento de Bolívar que emplearon la secuenciación Sanger identificaron las variantes genéticas S436F- K540E en pfdhps y T958M en pvmdr-1. Conclusiones: Existen pocos estudios de marcadores moleculares asociados a resistencia antimalárica en la región, por lo que estamos lejos de definir el perfil de resistencia antimalárica en el Caribe colombiano. Es necesario hacer vigilancia molecular empleando tecnologías de vanguardia.

Palabras clave: Marcadores genéticos, Resistencia, Antimalárica, Caribe, Colombia

Citación (Vancouver): Marcadores moleculares asociados a resistencia antimalárica en la región Caribe Colombiana: Estado del conocimiento. Rev Avances en Salud; 2021. (5)1:20-21 doi: $10.21897 / 25394622.2519$

\footnotetext{
'Biólogo, M.Sc Laboratorio Departamental de Salud Pública La Guajira. Riohacha, La Guajira - Colombia. Correspondencia: fdelacruzlopez10@gmail.com.

${ }^{2}$ Biólogo, Grupo de Entomología, Dirección de Investigación en Salud Pública - Instituto Nacional de Salud de Colombia INS, Bogotá

- Colombia. lacuna@ins.gov.co.

${ }^{3}$ Químico Farmacéutico M.Sc, Grupo de Inmunología y Biología Molecular, Universidad del Atlántico. Barranquilla, Atlántico Colombia.alfredolagares@mail.uniatlantico.edu.co.

${ }^{4}$ Licenciada en Biología y Química M.Sc, Grupo de Inmunología y Biología Molecular, Universidad del Atlántico. Barranquilla, Atlántico - Colombia. lourdesvarela@mail.uniatlantico.edu.co.

${ }^{5}$ Química Farmacéutica, Ph.D, Grupo de Productos Naturales y Bioquímica de Macromoléculas, Universidad del Atlántico. Barranquilla, Atlántico - Colombia. darymendoza@mail.uniatlantico.edu.co.
} 


\section{ABSTRACT}

Objective: Review the state of knowledge of molecular markers associated with antimalarial drug resistance in the Colombian Caribbean. Methods: A systematic review of scientific literature the available scientific literature was conducted about molecular markers associated with antimalarial drug resistance. The search was done in databases following criteria: "PCR" "Plasmodium falciparum" "Plasmodium vivax" "Resistance" "Antimalarial" "genes" in departments of: Atlántico, Bolívar, Cesar, La Guajira, Magdalena, Sucre and the San Andrés, Providencia and Santa Catalina Islands between 2000-2020. Results: Four studies were included in Sucre (2005), Magdalena (2010) and Bolívar (2013 and 2017) departments. The genetic variants S108N in pfdhfr and A437G in pfdhps of P.falciparum were identified in Sucre and Bolivar respectively, K76T in pfcrt of P.falciparum in Magdalena and F1076L - Y976F of pvmrd-1 in P.vivax de Bolívar. Studies of Bolívar department that used Sanger sequencing identified the genetic variants S436F-K540E in pfdhps and T958M in pvmdr-1. Conclusions: There are few studies of molecular markers associated with antimalarial drug resistance in the Colombian Caribbean, which indicates that we are far from defining the antimalarial resistance profile in the Colombian Caribbean. The molecular surveillance is necessary using the recent technologies.

Key words: Molecular markers, Resistance, Antimalarial, Caribbean, Colombia.

\section{REFERENCIAS}

1. Aljure S, Mendoza K, Mendoza-Meza DL, Blanco P. Determinación de la mutación asn-108 del gen dhfr de Plasmodium falciparum asociada con resistencia «In vitro» a pirimetamina en aislados del departamento de Sucre, Colombia. Duazary. 2005;
2(2):87-94. doi:0.21676/2389783X.289.

2. Domínguez Moré $G$, Santander Altamar, Lagares Guzmán A, Mendoza-Meza DL. Determinación de la mutación K76T de la proteína transportadora resistente a Cloroquina de Plasmodium falciparum (pfcrt) en individuos con malaria en una zona de transmisión moderada del Caribe colombiano. Salud Uninorte. 2010; 26(1):77-84.

3. Mendoza-Meza DL, Acuña-Cantillo L, De la Cruz López F, Lagares-Guzmán A, Varela Prieto L. Mutaciones puntuales en el gen de la dihidropteroato sintetasa de Plasmodium falciparum en Bolívar, Colombia. Rev Cubana Med Trop. 2013; 65(2): 242-248.

4. -Torres-Iglesias A, Lagares Guzman A, Varela Prieto L. Identificación de la mutación F1076L en el gen mrd-1 aislado de muestras de Plasmodium vivax obtenidas del sur de Bolívar, Colombia [Pregrado]. Universidad delAtlántico. 2018. 